\title{
Evaluation of Load-Transfer Efficiency of Steel Mesh Reinforced Contraction Joints in Concrete Pavement: Accelerated Pavement Test and FE Analysis
}

\author{
Muhammet ÇELIK ${ }^{1}$ \\ Mehmet Tevfik SEFEROĞLU ${ }^{2}$ \\ Muhammet Vefa AKPINAR ${ }^{3}$ \\ Mohammad Manzoor NASERY ${ }^{4}$ \\ Ayşegül Güneş SEFEROĞLU ${ }^{5}$
}

\begin{abstract}
Transverse contraction joints are by far the most common type of joint in jointed plain concrete pavements. Early loading of contraction joints can create a weakened vertical plane and later grow as a full-depth crack. In this study, load transfer efficiency (LTE) of steel mesh reinforced transverse contraction joints were studied at accelerated pavement tests (APT). 3D finite element (FE) model of jointed plain concrete pavement (JPCP) was developed to study deflections and crack propagation in just under the joint of the concrete pavement. The APT tests were focused on the LTE values before and after the crack initiation under the contraction joint region. Experiments were performed on three slabs in which two of these slabs were prepared without reinforcement and one of them was reinforced with steel mesh. Data generated by APT was used for verification of crack propagation modeling in the finite element analysis. Steel mesh reinforced slab gave the lowest vertical deflections $(51 \mu \mathrm{m})$ and highest LTE (91.56\%). The LTE value in the reinforced slab after 25,000 passes was $13.63 \%$ higher than the average of unreinforced slabs. The findings suggest that the load transfer efficiency was found to be a complex parameter and should be interpreted together with average displacement values when contraction joints are evaluated at early traffic loadings.
\end{abstract}

Note:

- This paper was received on November 5, 2019 and accepted for publication by the Editorial Board on April 17, 2020.

- Discussions on this paper will be accepted by January 31, 2022.

- https://doi.org/10.18400/tekderg.643027

1 Yalova University, Department of Civil Engineering, Yalova, Turkey m.celik53@gmail.com - https://orcid.org/0000-0002-3998-8146

2 Gumushane University, Department of Civil Engineering, Gümüşhane, Turkey mtseferoglu@gmail.com - https://orcid.org/0000-0003-4677-3335

3 Karadeniz Technical University, Department of Civil Engineering, Trabzon, Turkey mvakpinar70@yahoo.com - https://orcid.org/0000-0001-7912-8274

4 Karadeniz Technical University, Department of Civil Engineering, Trabzon, Turkey manzoor.nasery@gmail.com - https://orcid.org/0000-0003-3787-1355

5 Gumushane University, Department of Civil Engineering, Gümüşhane, Turkey gnskaya61@gmail.com - https://orcid.org/0000-0002-1008-6456 
Keywords: Accelerated pavement test, finite element analysis, concrete pavement, transverse contraction joint, steel mesh reinforcement.

\section{INTRODUCTION}

Concrete pavements are exposed to different stresses due to traffic loads and environmental conditions. These stresses cause uncontrolled cracks in concrete slabs over time. Contraction joints are made to ensure that these cracks occur in the weakened section [1]. Sawed concrete pavement joints are widely used in paving and industrial construction for efficient and costeffective crack control $[2,3]$. Saw cut joints minimize random cracking due to temperature changes and drying shrinkage. The weakened sections created by the joint cause the cracks to form at these locations. Cracking occurs beneath the sawed region as soon as the tensile stress overcomes the tensile strength of the concrete.

Contraction joints are one of the easiest and most economical methods to ensure the load transfer between the slabs $[2,3]$. Contraction joints are usually cut 1/6-1/3 of the slab depth using wet or dry conventional contraction methods [4, 5]. Micro cracks just below the contraction joints start developing as soon as the road is open to traffic. However, these cracks also help to carry the vertical loads due to the internal friction between the aggregates at the joints [6-8].

Load transfer in concrete pavements is the capacity of a joint to transfer a portion of the wheel load from one side of the joint to the next. The load transfer is accomplished by steel reinforcement, aggregate interlock across adjacent edges of concrete slabs and friction between the concrete and stabilized base $[6,7]$. For unreinforced jointed plain concrete pavement (JPCP), aggregate interlock underneath the saw cut portion of the joint provides the majority of the load transfer [5]. After the crack formation, the load transfer diminishes marginally $[8,9]$. Over time these aggregate interlock faces can wear and load transfer can drop down, especially when there is no reinforcement. The field observation of the splits under a contraction joint is demonstrated in Fig. 1.
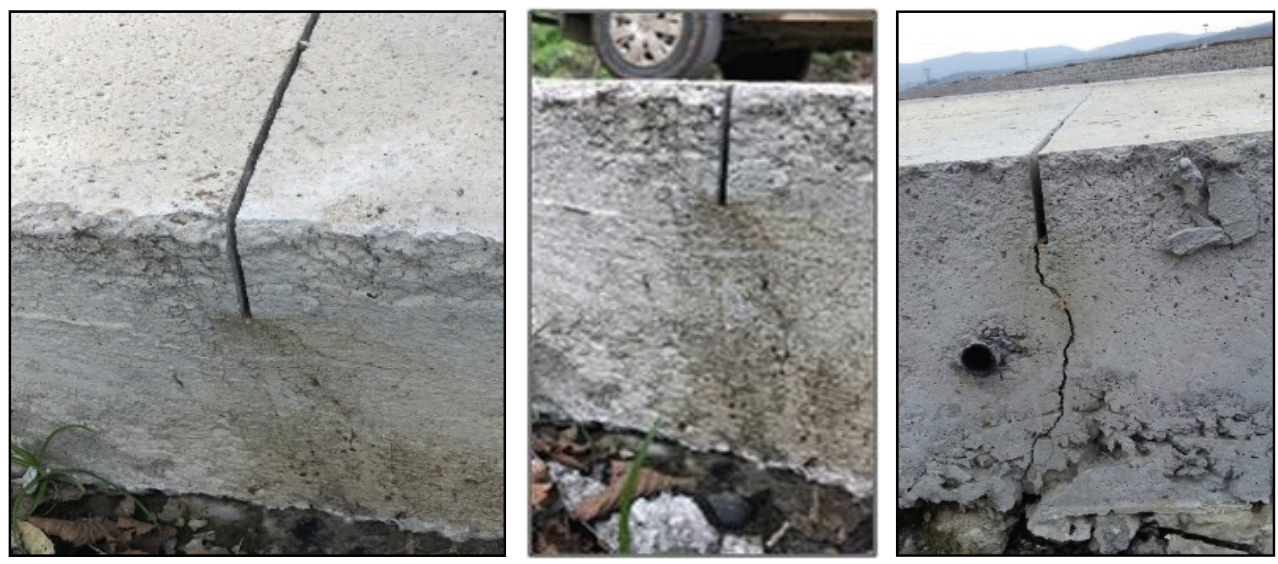

Figure 1 - Crack observation under the contraction joint in-service pavement

(Trabzon/Turkey). 
The repetitive traffic loading induced vertical deflections to cause the pavement to deteriorate early [10-12]. Vertical deflections vary according to many factors such as; concrete slab sizes, the thickness, load type, load repetition, base/sub-base conditions, joint type, joint depth, the presence of reinforcement, the vertical and horizontal slope of pavement,... etc. [13]. 'Load transfer efficiency', 'load transfer' and 'joint transfer efficiency' are terms that have been used by researchers to define the load transfer mechanism between the concrete slabs [14-15]. Deflection based LTE can be defined as a surface deflection measured on an unloaded slab relative to that on a loaded slab. Higher LTE at a joint indicates that traffic loading can result in lower vertical deflection [16].

The need for faster and more practical assessment methods that closely simulate service conditions has required the consideration of accelerated pavement testing (APT) facilities. APT develops road technology and provides an understanding of the performance of pavement systems while producing early, reliable and useful results [17, 18]. The APT system can be defined as a system that simulates the actual loading conditions that will affect the pavement in the field by simulating it in a controlled manner. The performance of the pavement in APT facilities can be achieved in a much shorter period than in the field. The 520 years of traffic loads can be carried out in 3-12 months with APT. Moreover, environmental conditions (temperature, humidity...) can be simulated and the response of the pavement in different ambient conditions can be obtained [19-23].

In this study load-transfer efficiency of steel mesh reinforced contraction joints in concrete pavement using the accelerated pavement test and FE analysis is evaluated. FE model of JPCP was developed using ABAQUS software to study deflections and crack propagation under the concrete pavement. The analysis focused on the LTE values before and after the crack initiation under the contraction joint. Finally, the cost-benefit analysis of using steel mesh reinforcement has been made.

\section{EXPERIMENTAL PROGRAM}

\subsection{APT Facility}

The scope of the APT facility was utilized to investigate $4 \mathrm{~m} \times 2 \mathrm{~m} \times 180 \mathrm{~mm}$ (thick) JPCP slabs as shown in Fig. 2 and Fig. 3. The test sections were constructed on top of a $300 \mathrm{~mm}$ thick base layer of natural gravel with a CBR of $80 \%$. Average surface vertical deflections for each APT section were measured by LVDTs (linear variable differential transformers).

Each test section was applied for 1,000 passes/day with $0.80 \mathrm{MPa}$ double wheels LVDTs were placed on both sides of the joint and the data were collected. During the testing program, the air temperature inside the APT facility varied between $21-25^{\circ} \mathrm{C}$ and the concrete surface temperature varied between $20-21^{\circ} \mathrm{C}$ and the bottom of the slab varied between $19-20^{\circ} \mathrm{C}$. The difference between the top and bottom of the concrete was around $3^{\circ} \mathrm{C}$ which can be ignored when thermal effects are considered. The average relative humidity varied from 50 to $60 \%$. Freeze-thaw effects were not considered in APT tests unless the tests were specifically designed to include these effects. 


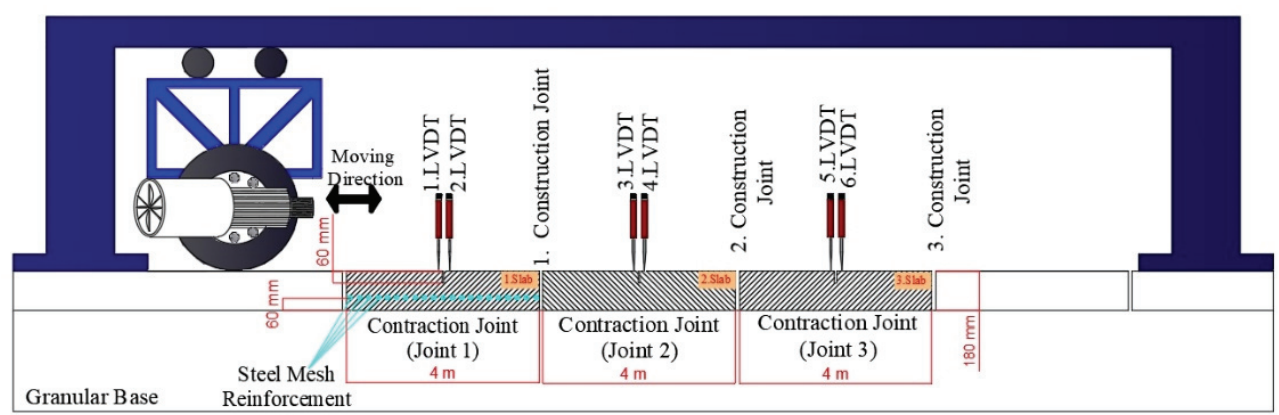

Figure 2 - Side view of the test section

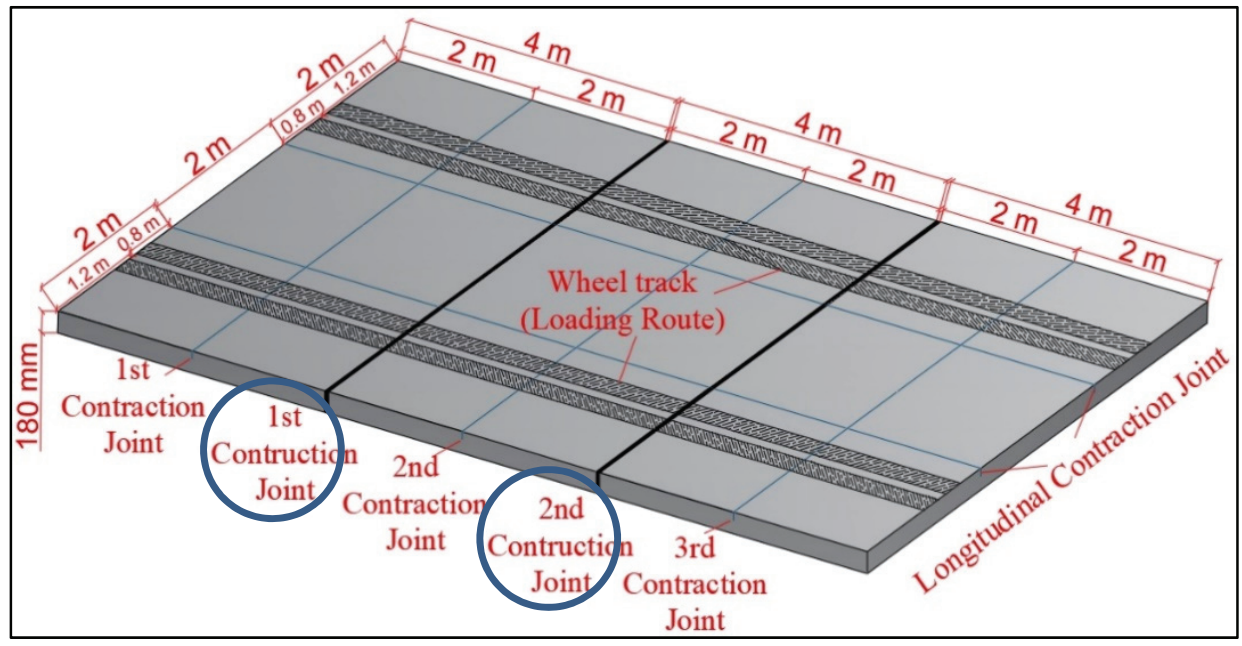

Figure 3 - Construction and contraction joints

\subsection{Materials}

\subsubsection{Concrete Pavement, Base and Subbase Layer}

The existing $180 \mathrm{~mm}$ thick concrete pavement was made of CEM I 42.5 Portland cement having a characteristic compressive strength of $25 \mathrm{MPa}$. C25 standardized mix concrete is widely versatile and used in numerous commercial and domestic concrete pavement projects. The early core samples collected on the county roads showed that the concretes had typical C25 characteristics. The concrete density was $2,400 \mathrm{~kg} / \mathrm{m}^{3}$, tensile strength was $1.9-2 \mathrm{MPa}$. The testing program started three months after the concrete was paved in order to eliminate the strength parameter.

The most commonly specified steel mesh for paving works is A142 (6 mm wires), A193 (7 $\mathrm{mm}$ wires) and A252 (8 mm wires). A142 mesh is frequently utilized in $100 \mathrm{~mm}$ thick driveways and parking lots, although A252 is generally used in $150-200 \mathrm{~mm}$ thick slabs. As 
shown in Fig. 4, the first slab was made of A252 steel mesh reinforced type, while the other two slabs were unreinforced. The section where steel mesh reinforcement spacing was 150 $\mathrm{mm} \times 150 \mathrm{~mm}$. The concrete slab was paved over a $300 \mathrm{~mm}$ thick granular base layer.

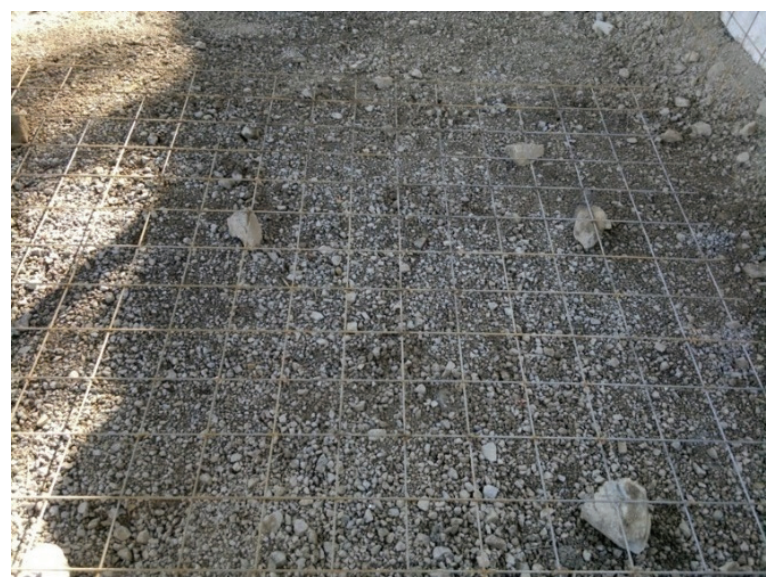

Figure 4 - Mesh reinforcement was positioned $60 \mathrm{~mm}$ above the base layer

Table 1. Material Characteristics

\begin{tabular}{|c|c|c|c|c|c|c|}
\hline Layer & $\begin{array}{c}\text { Thickness } \\
(\mathrm{mm})\end{array}$ & $\begin{array}{c}\text { Dry unit } \\
\text { weight } \\
\left(\mathrm{kg} / \mathrm{m}^{3}\right)\end{array}$ & $\begin{array}{c}\text { Elastic/ } \\
\text { Modulus } \\
(\mathrm{MPa})\end{array}$ & $\begin{array}{c}\text { CBR } \\
(\%)\end{array}$ & $\begin{array}{c}\text { Moisture } \\
\text { Content } \\
(\%)\end{array}$ & $\begin{array}{c}\text { Relative } \\
\text { Compaction } \\
(\%)\end{array}$ \\
\hline Concrete & 180 & 2,400 & 32,000 & - & - & - \\
\hline Base & 300 & 2,100 & 300 & 80 & 5 & 98 \\
\hline Subbase & 1,000 & 1,900 & 100 & 60 & 6 & 95 \\
\hline
\end{tabular}

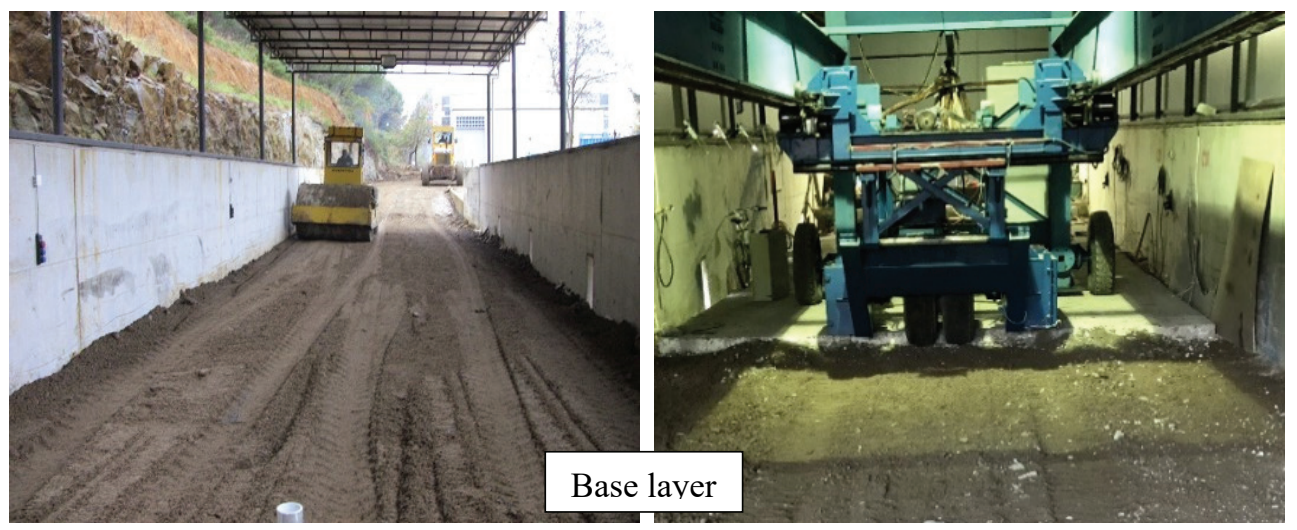

Figure 5 - The base layer beneath the concrete pavement 
Figure 5 shows the compacted base and subbase layers and Table 1 shows the material characteristics. The base layer moisture content was maintained constant at $5 \%$ and no hydro-pumping effect was observed during the test. In terms of moisture content, the aggregate base moisture content of $5 \%$ was relatively low.

\subsubsection{Contraction Joints}

Contraction joints were applied on the centerline of the concrete slabs $(4 \mathrm{~m} \times 2 \mathrm{~m})$ as shown in Fig. 3. The slabs were apart from each other with construction joint (full depth joint), meaning that their deflections were not influenced by the adjacent ones. Full depth construction joints and contraction joints had $20 \mathrm{~mm}$ and $5 \mathrm{~mm}$ openings, respectively. The contraction joints were obtained by cutting down to $1 / 3(60 \mathrm{~mm})$ of the concrete slab depth $(180 \mathrm{~mm})$ as shown in Fig. 6. Consistent joint dimensions (same width and depth of each cut) were obtained. Typically, for jointed unreinforced concrete pavements, the joint spacing is about 30 times the thickness with the maximum spacing of $4.5 \mathrm{~m}$. Generally, 3.7-4.6 $\mathrm{m}$ joint spacing is recommended as appropriate for concrete pavements with $180 \mathrm{~mm}$ thickness [24].
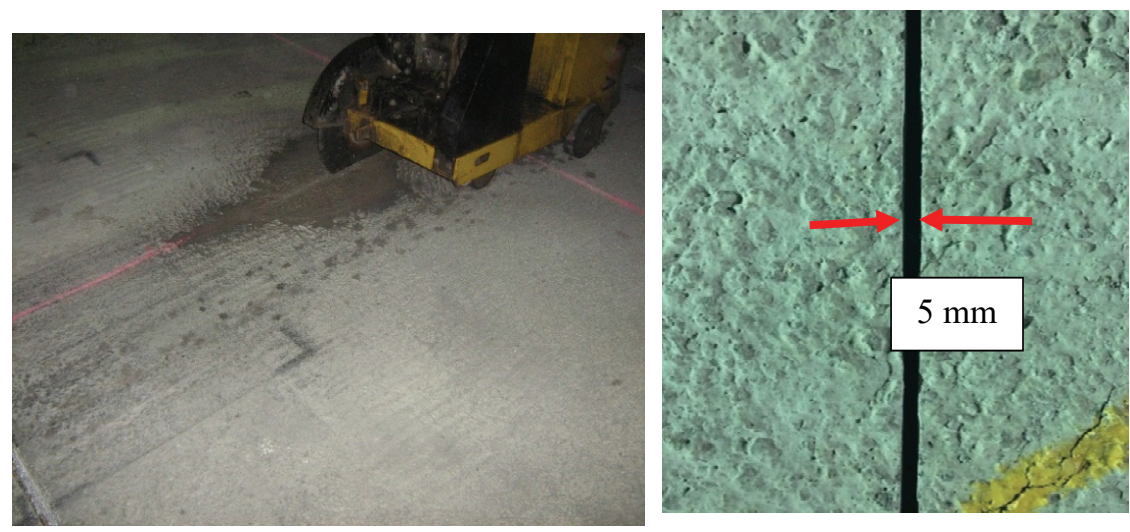

Figure 6 - Saw-cut contraction joint and joint openings

\subsection{Test set-up}

Vertical deflections under loading in contraction joints were monitored by LVDTs. To eliminate undesired excessive vibration deflections caused by moving wheels, the deflection sensors were mounted to the wall near the slab. The LVDT is capable of measuring up to 150 $\mathrm{mm}$ one hundred million translations from $-20^{\circ} \mathrm{C}$ to $+80^{\circ} \mathrm{C}$. Figure 7 shows the locations of the LVDTs placed along the slab edges.

A uniform contact pressure of $0.8 \mathrm{MPa}$ was maintained below each wheel passing. Pressure cells were placed on the slabs for calibration of the two wheels before and during the tests (Fig. 8). A total of 25,000 passes were made on the pavement lane and a total of 1,000 loads per a day were applied. The speed of the dual wheels was adjusted to $3 \mathrm{~km} / \mathrm{h}$ in order to represent the heavy vehicle effect. In this study similar to literature the speed was adjusted 
to $3 \mathrm{~km} / \mathrm{h}$ in order to obtain an early crack at the joints. Similar loads and speeds were used by early studies [25-30].
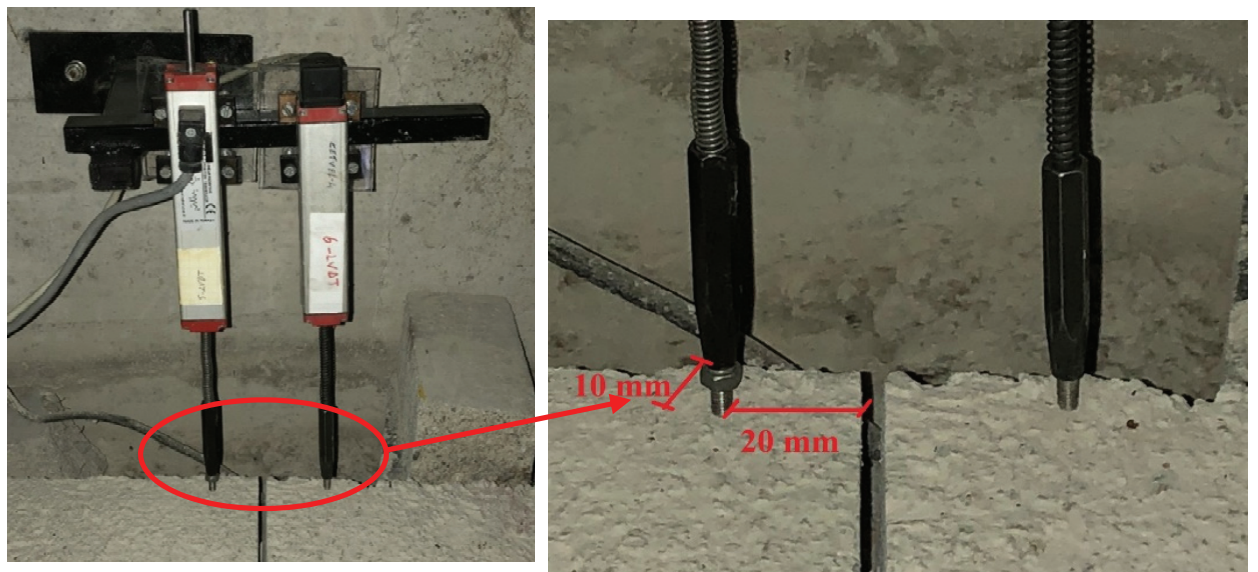

Figure 7 - The LVDTs at both sides of the joint were mounted on the wall

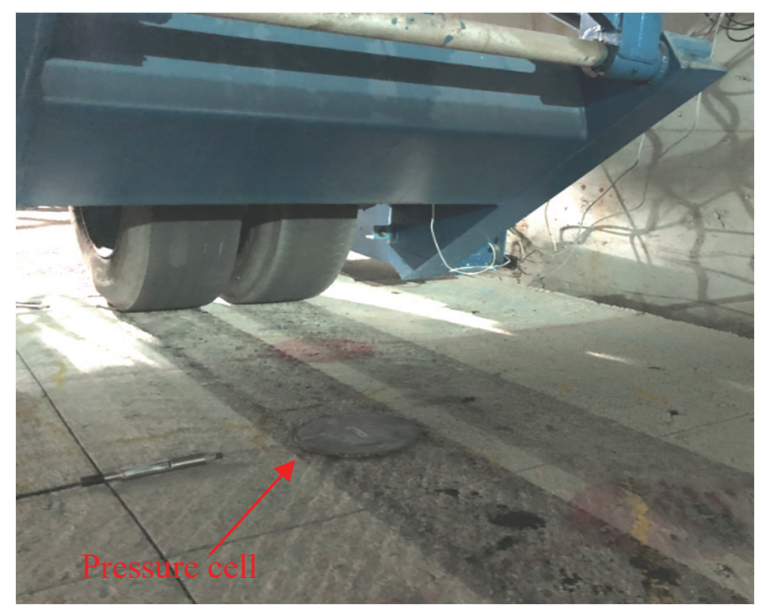

Figure 8 - The pressure cell

\subsection{FE Modeling}

A nonlinear 3D FE model was developed using ABAQUS version 6.12 to determine numerically the behavior of the contraction joints and induced cracks in the concrete slabs. As seen in Fig. 9, four different models (before and after the crack initiation) were examined in the finite element analysis.

To reduce the analysis time, only the space between the three joints was modeled. In the modeling process, the eight-node brick element with reduced integration (C3D8R) element 
type was used in concrete slabs, base layer, and subbase layers. While for the reinforcement mesh a 2-node linear 3-D truss element (T3D2) was used (Fig. 10).
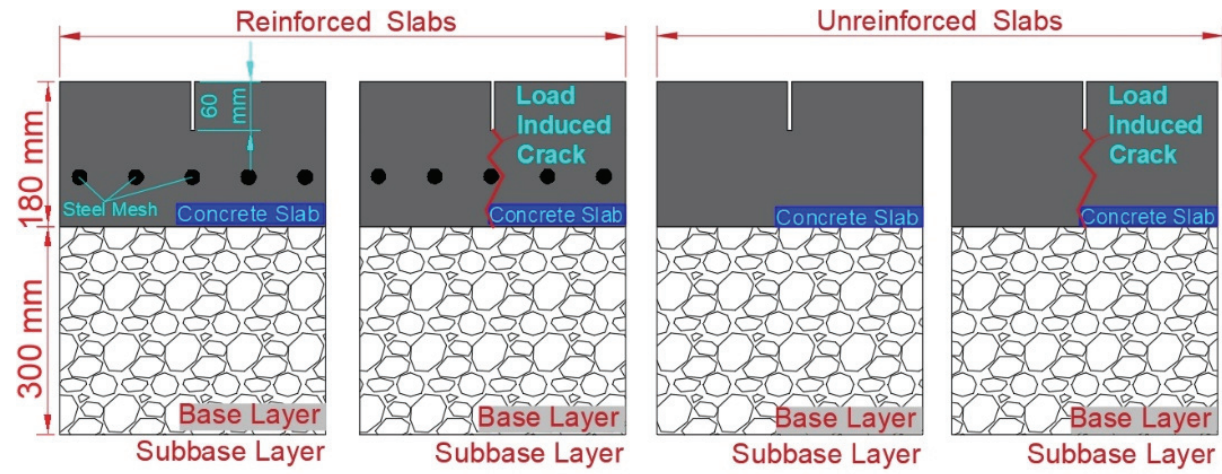

Figure 9 - Reinforced and unreinforced FEM models before and after the crack initiation

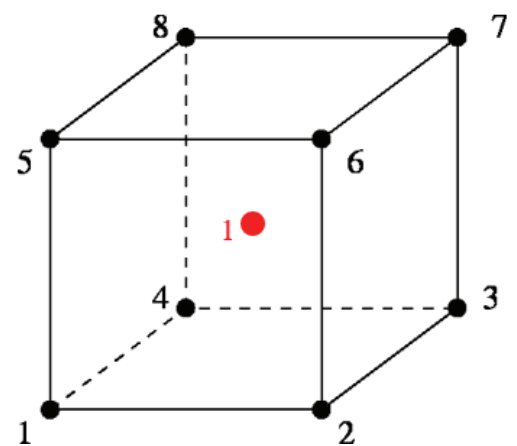

(a)

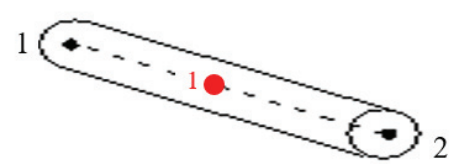

(b)

Figure 10 - (a) Eight-node brick element with reduced integration (C3D8R) (b) 2-node linear 3-D truss element [31]

To simulate the tire pressure during the nonlinear finite element analysis, two blocks were modeled with a similar dimension of the tire footprint $300 \mathrm{~mm} \times 250 \mathrm{~mm}$ which was used in the experimental study. Frictional tangential behavior properties were used in the surface to surface contact elements representing the contact between the layers. To idealize the subgrade in FE models, built-in boundary condition were assigned to the bottom of the subbase layer. In this condition, all degrees of freedoms have been limited. The defined boundary condition, exerted tire pressure and three dimensional FE model with saw joint are presented in Fig. 11.

One of the main aims of the study was the investigation of cracks in concrete slabs especially near the joints. To simulate the crack progression and stiffness degradation of the material, concrete damaged plasticity (CDP) material models were used. In ABAQUS, the stress-strain 
curve must be defined to CDP model for both compression and tensile under uniaxial. During the study concrete slabs were paved with $\mathrm{C} 25$ class concrete, which means that the compressive strength of the concrete was $25 \mathrm{MPa}$. The idealized stress-strain curves of concrete in the experimental study were defined in the CDP model. Stiffness degradation parameters for both compression and tension were also defined by the mechanical properties of the CDP model. In addition, the material properties which were used in the CDP model are summarized in Table 2 [32]. For the simulation of the soil and compacted gravel layers, the most common material model is Drucker Prager Hardening model [33]. Therefore, in the base and subbase layers the Drucker Prager Hardening material model was used. The elasticity model was taken as $300 \mathrm{MPa}$ for the base layer and $100 \mathrm{MPa}$ for subbase layer. For both materials, the Poisson ratio was defined as 0.3 [34].

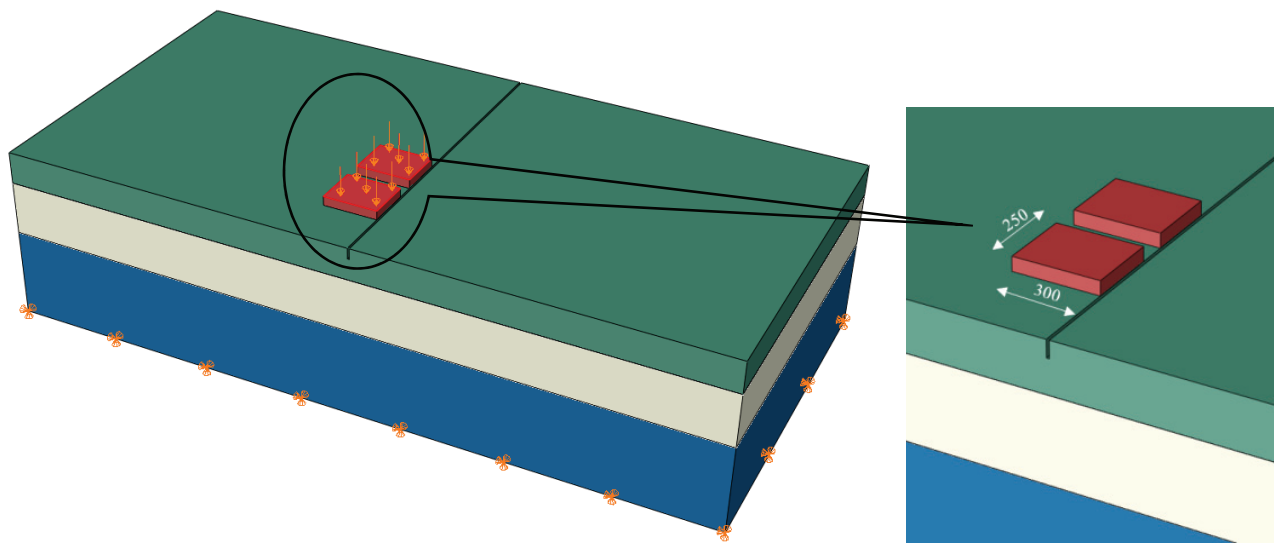

Figure 11 - FE model with saw joint, tire pressure and boundary conditions

Table 2 - Material properties and parameters of C25 concrete [32]

\begin{tabular}{|l|c|c|}
\hline $\begin{array}{l}\text { Initial modulus } \\
\text { of elasticity }\end{array}$ & $\begin{array}{c}\mathrm{E}_{\mathrm{o}} \\
(\mathrm{MPa})\end{array}$ & 32,000 \\
\hline Poisson ratio & $\mathrm{v}$ & 0.2 \\
\hline Density & $\begin{array}{c}\rho \\
\left(\mathrm{kg} / \mathrm{m}^{3}\right)\end{array}$ & 2,400 \\
\hline $\begin{array}{l}\text { Compressive } \\
\text { Strength }\end{array}$ & $\begin{array}{c}\mathrm{Fck} \\
(\mathrm{MPa})\end{array}$ & 25 \\
\hline $\begin{array}{l}\text { Peak strain of } \\
\text { compressive }\end{array}$ & $\varepsilon$ & 0.002 \\
\hline Ultimate strain & $\varepsilon \mathrm{u}$ & 0.0034 \\
\hline
\end{tabular}

\begin{tabular}{|l|c|c|}
\hline $\begin{array}{l}\text { Ratio of initial equi-biaxial } \\
\text { compressive yield stress to initial } \\
\text { uniaxial compressive yield stress }\end{array}$ & Fbo/Fco & 1.16 \\
\hline Max. damage parameter of tensile & $\mathrm{dt}$ & 0.99 \\
\hline $\begin{array}{l}\text { The ratio of the second stress } \\
\text { invariant on the tensile meridian to } \\
\text { that on the compressive meridian }\end{array}$ & $\mathrm{Kc}$ & 0.667 \\
\hline Eccentricity & $e$ & 0.01 \\
\hline Dilation angle & $\Psi$ & 36 \\
\hline Tensile strength & $\begin{array}{c}\text { Fctk } \\
\text { (MPa) }\end{array}$ & 1.9 \\
\hline
\end{tabular}


After a set of studies, the mesh element size of the concrete, base, and space was determined as $20 \mathrm{~mm}$. However, the contraction distance was $5 \mathrm{~mm}$, to optimize the analysis duration and obtain the best crack distribution, the area near to the joints were meshed as $5 \mathrm{~mm}$. 3D finite element model with intensive mesh near the joint area is shown in Fig. 12.

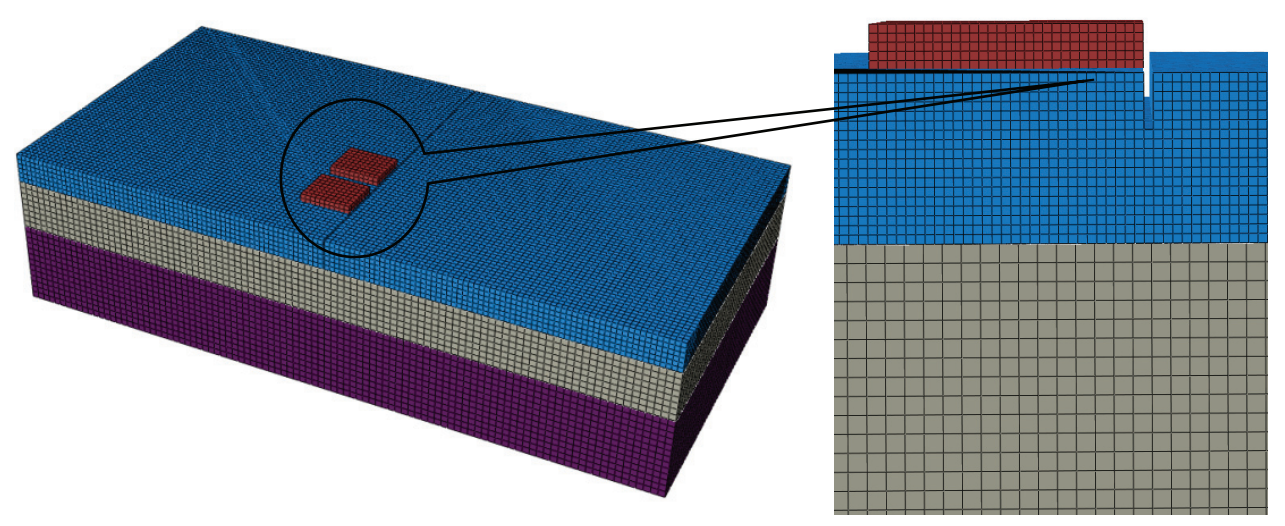

Figure 12 - FE modeling of the saw cut contraction joint with intensive mesh near the joint area

\section{RESULTS AND DISCUSSION}

\subsection{APT Results}

\subsubsection{Deflection Results}

In this study, LTE values were calculated using Eq. 1 [35] which is the most commonly used LTE AASHTO formula.

$(\%) L T E=\frac{\delta_{\mathrm{U}}}{\delta_{\mathrm{L}}} \times 100$

Where, $\delta_{\mathrm{L}}$ and $\delta_{\mathrm{U}}$ are deflection values obtained from the joint on the loaded (approach) and unloaded (leave) slab, respectively.

Figure 13 shows the measured deflections at the initial and the final loadings $(25,000)$, respectively. LVDT sensors numbered as 1,3 and 5 measured deflections near the tire load. At the same time LVDTs 2, 4 and 6 measured the deflections on the opposite side of the joints, as shown in Fig. 13. As seen in Fig. 13, joint-1 is located on the center of the steel mesh reinforced slab; joint-2 and joint- 3 is located on the slab with no steel reinforcement. Joint-2 and joint-3 refer to two contraction joints at adjacent slabs with the same characteristics (same dimensions and strength) with no mesh steel reinforcement. 


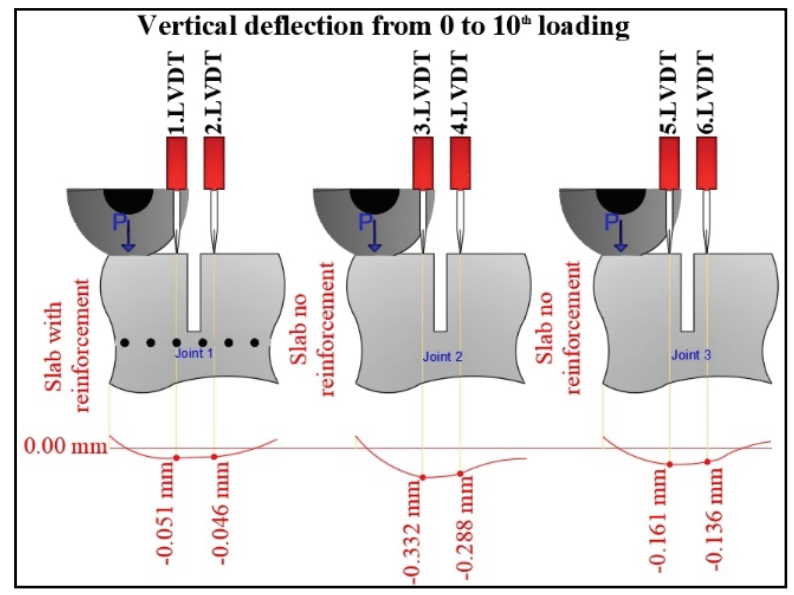

(a)

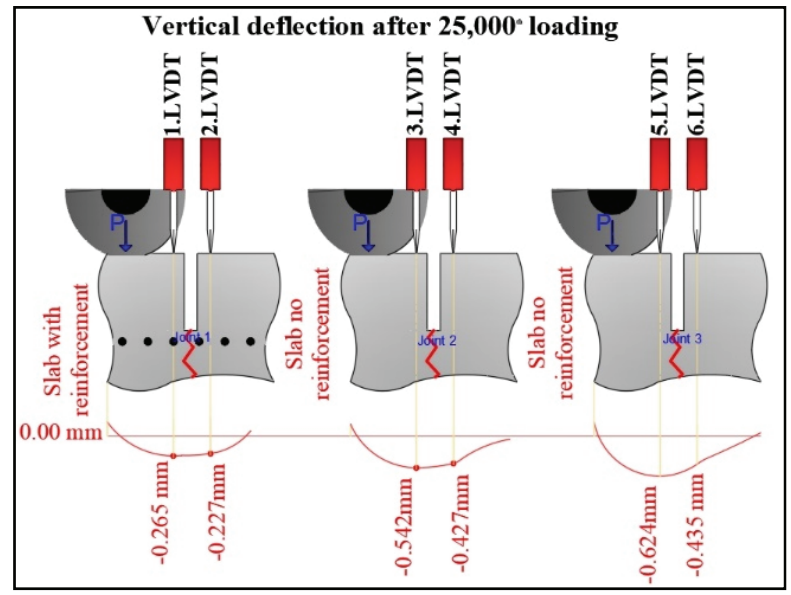

(b)

Figure 13 - Vertical deflections (a) at first loading and (b) after 25,000 loadings

Figure 14 shows the measured vertical deflections at the beginning of the slab and at the contraction joints. The positive values in Fig. 14 indicate that the displacement at the far end of the slab (A and $\mathrm{C}$ ) whereas the negative ones indicate the deflection at the joint (B). B measuring negative and positive deflections at the same time indicates that the slab was behaving as a cantilever beam. This was expected due to the material used in the base layer as it was well compacted with a high CBR value of $80 \%$. This also indicated that the bearing factor on the measurements could be neglected.

A summary of collected deflection data on the APT test sections is presented in Table 3 and Table 4 and shown in Fig. 15. The data show significant variability among the test sections. 
Considering the vertical deflections, reinforced slab gave the lowest vertical deflections for loaded $(51 \mu \mathrm{m})$ and unloaded $(46.7 \mu \mathrm{m})$ cases $\left(\delta_{\text {ave }} 48.85 \mu \mathrm{m}\right)$.

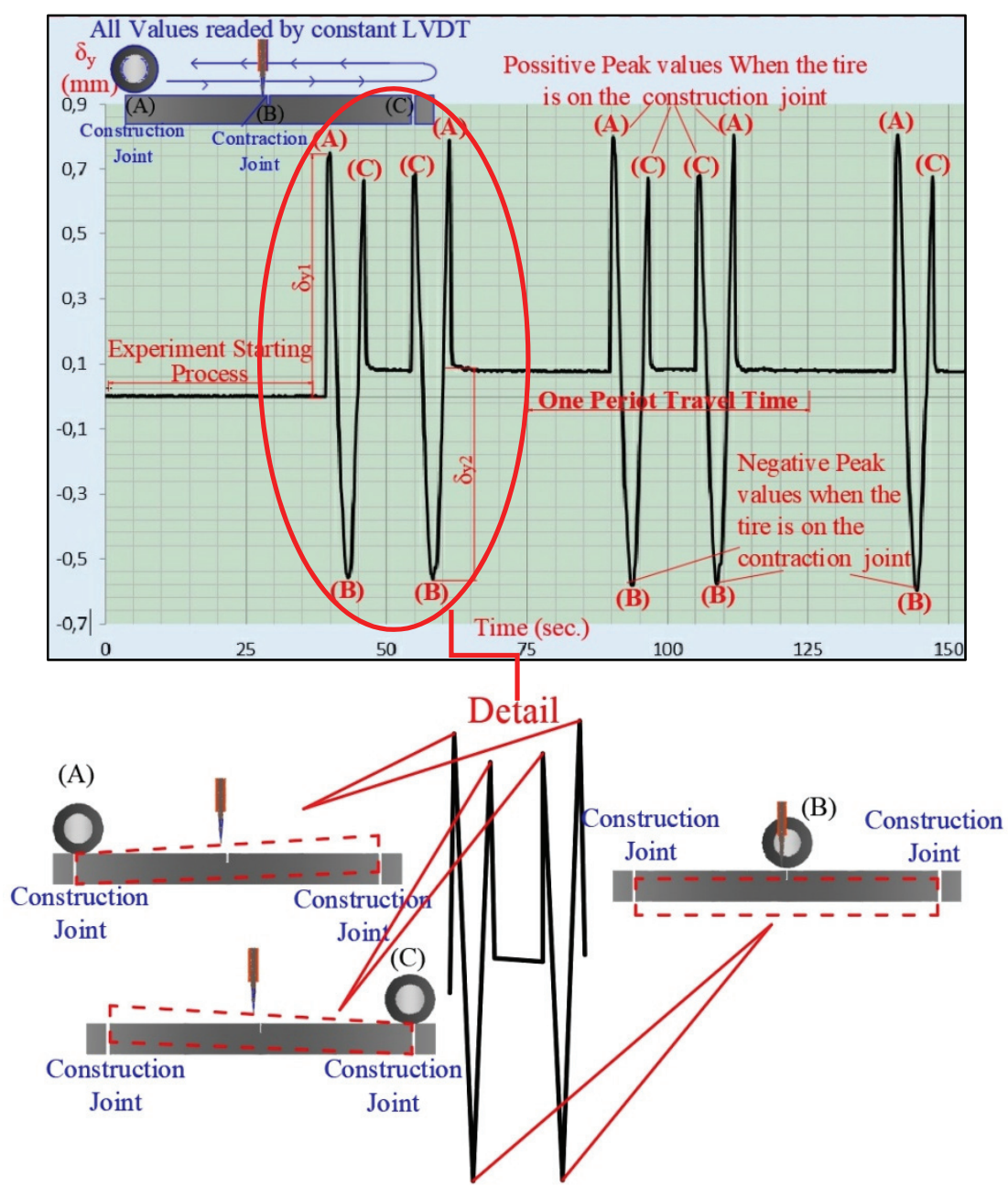

Figure 14 - Measured vertical deflections versus time

Figure 15 shows the graphics of each slab vertical deflection during 550 sec. (10 passes) measurement for reinforced slab and two unreinforced slabs (joint $_{2}$ and joint 3 ). The vertical deflection values did not change $(0.02 \mathrm{~mm})$ for reinforced slab under initial loadings (10 passes), but after 25,000 loads they increased up to $0.4 \mathrm{~mm}$.

Average vertical deflection $\left(\delta_{\text {ave }}\right)$ refers to the mean of deflections on the slab edges on both sides of the joint [35]. The $\delta_{\text {ave }}$ and LTE values obtained from the slabs in the first loading and the final $(25,000$ th) loading are given in Table 3 and Table 4 , respectively. 

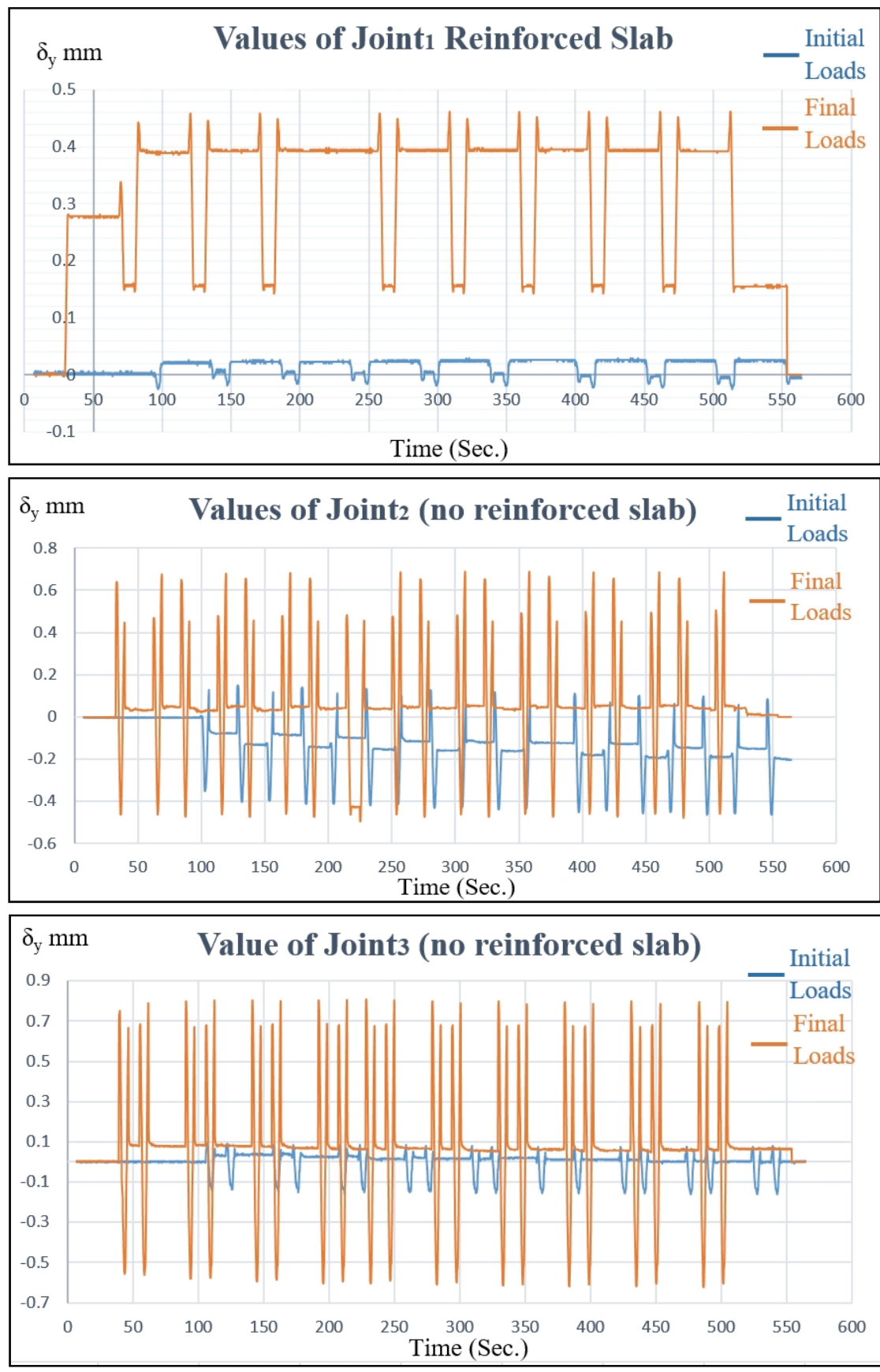

Figure 15 - Curves of vertical deflection in each slab for (a) reinforced slab, (b) and (c) unreinforced slabs 
Table 3 - Save and LTE values in the initial loadings (0-10 loading)

\begin{tabular}{|c|c|c|c|c|c|c|}
\hline \multirow[b]{2}{*}{ Joint Type } & \multicolumn{2}{|c|}{ Vertical deflections $(\delta), \mu \mathrm{m}$} & \multirow{2}{*}{\multicolumn{2}{|c|}{$\begin{array}{c}\text { LTE, \% } \\
\left(\delta_{\mathrm{U}} / \delta_{\mathrm{L}}\right) \times 100\end{array}$}} & \multirow{2}{*}{\multicolumn{2}{|c|}{$\begin{array}{l}\delta_{\text {ave }}, \mu \mathrm{m} \\
\left(\delta_{\mathrm{L}}+\delta_{\mathrm{U}}\right) / 2\end{array}$}} \\
\hline & $\begin{array}{c}\text { Loaded side of the } \\
\text { joint, } \delta_{\mathrm{L}}\end{array}$ & $\begin{array}{l}\text { Unloaded side of } \\
\text { the joint, } \delta_{U}\end{array}$ & & & & \\
\hline Steel reinforced joint ${ }_{1}$ & 51 & 46.7 & \multicolumn{2}{|c|}{91.56} & \multicolumn{2}{|c|}{48.85} \\
\hline No reinforcement joint ${ }_{2}$ & 332 & 288 & 86.74 & \multirow{2}{*}{$\begin{array}{l}\text { Ave. } \\
85.75\end{array}$} & 310 & \multirow{2}{*}{$\begin{array}{c}\text { Ave. } \\
229.25\end{array}$} \\
\hline No reinforcement joint ${ }_{3}$ & 161 & 136 & 84.77 & & 148.5 & \\
\hline
\end{tabular}

Table 4 - $\delta_{\text {ave }}$ and LTE values after 25,000 loadings

\begin{tabular}{|c|c|c|c|c|c|c|}
\hline \multirow[b]{2}{*}{ Joint Type } & \multicolumn{2}{|c|}{ Vertical deflections $(\mu \mathrm{m})$} & \multirow{2}{*}{\multicolumn{2}{|c|}{$\begin{array}{c}\operatorname{LTE}(\%) \\
\left(\delta_{\mathrm{U}} / \delta_{\mathrm{L}}\right) \times 100\end{array}$}} & \multirow{2}{*}{\multicolumn{2}{|c|}{$\begin{array}{l}\delta_{\text {ave }}(\mu \mathrm{m}) \\
\left(\delta_{\mathrm{L}}+\delta_{\mathrm{U}}\right) / 2\end{array}$}} \\
\hline & $\begin{array}{l}\text { Loaded side of } \\
\text { the joint, } \delta_{\mathrm{L}}\end{array}$ & $\begin{array}{l}\text { Unloaded side of } \\
\text { the joint, } \delta_{U}\end{array}$ & & & & \\
\hline Steel reinforced joint ${ }_{1}$ & 265 & 227.8 & \multicolumn{2}{|c|}{85.96} & \multicolumn{2}{|c|}{246.4} \\
\hline No reinforcement joint $_{2}$ & 542 & 427 & 78.78 & \multirow{2}{*}{$\begin{array}{l}\text { Ave. } \\
74.24\end{array}$} & 484.5 & \multirow{2}{*}{$\begin{array}{c}\text { Ave. } \\
507\end{array}$} \\
\hline No reinforcement joint $_{3}$ & 624 & 435 & 69.71 & & 529.5 & \\
\hline
\end{tabular}

Significant differences were found between average vertical displacements, while the difference between LTE values was insignificant. There was a $6 \%$ difference between reinforced and unreinforced slabs in LTE values at initial loadings; however, the difference between the average displacement values was between $370 \%$. The differences reduce to 3.7 times after 25,000 passes. The use of steel mesh in concrete pavements reduced, but did not prevent the increase of vertical displacement movement at the completion of 25,000 passes.

When comparing contraction joint performance, the average displacement values measured on both sides of the joint can be a good indicator. This finding suggests that the average displacement values should be taken into consideration besides LTE when contraction joints are evaluated at early traffic loadings.

The highest LTE value (91.56\%) was measured in steel mesh reinforced concrete slab. Slab with reinforcement mesh gave the lowest LTE decrease rate of $6 \%$ after 25,000 passes. In contrast to mesh reinforced concrete slab, LTE rates decreased from $86.74 \%$ to $78.78 \%$ and $84.77 \%$ to $69.71 \%$ for second and third joints, respectively. The LTE difference between reinforced and unreinforced slabs was $6 \%$ before 25,000 passes and $13.6 \%$ when passes terminated.

Initial and final loading results showed major vertical deflection differences between the joints 2 and 3 even though both joints had the same thickness and the same material. A good explanation would be that the crack propagation at the joints was different and the interlock at the joints performed differently. But the visual inspection on the edges showed similar crack propagation. It is possible that the crack propagations were different elsewhere. 
The cracks on the concrete slab edges were observed every 1,000 loadings as shown in Fig. 16. Table 5 shows the observed initial cracks versus the wheel loading. It is clear that steel mesh reinforcement delayed the early cracks (at least 50\%) compared to the unreinforced slabs.

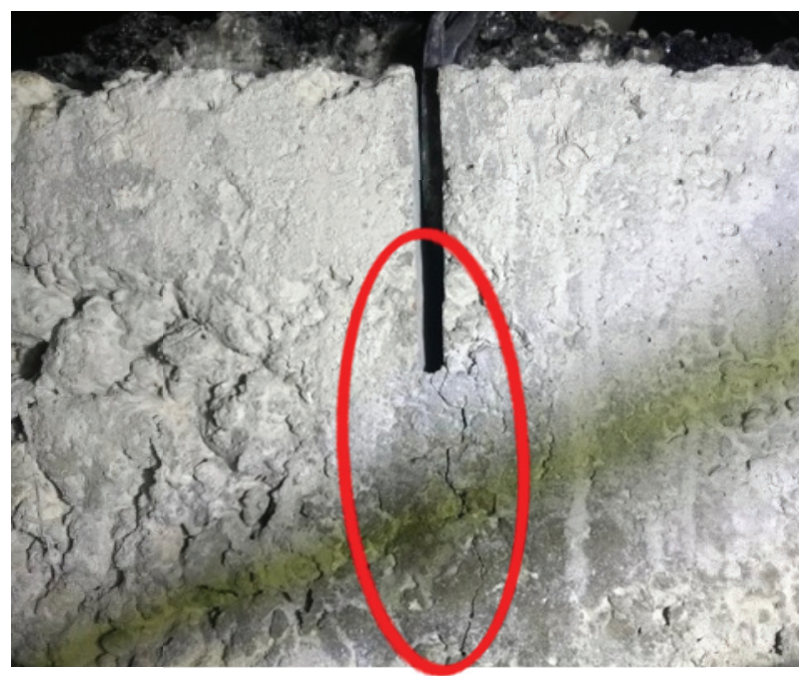

Figure 16 - Dual wheel induced cracks under the unreinforced contraction joint

Table 5 - First observed cracks under varying dual tire loads

\begin{tabular}{|c|c|}
\hline Joint type & Number of loading \\
\hline Joint $_{1}$ (steel mesh reinforced) & $10,000-11,000$ \\
\hline Joint $_{2}$ (unreinforced) & $4,000-5,000$ \\
\hline Joint $_{3}$ (unreinforced) & $3,000-4,000$ \\
\hline
\end{tabular}

\subsection{FE Analysis Results}

The predicted finite element results were almost similar to the real-time test results from APT. As seen in Fig. 17 irregular formation of cracks similar to the actual experiments was observed.

It was not possible to measure the deflections between and under the tires at the center of the PCC slab during the APT test. The vertical displacement and LTE values calculated by the finite element method are shown in Fig. 18 and are given in Table 6. Fig. 18 shows the vertical deflection distribution through the unreinforced slab. Vertical displacement of joint- 1 in the reinforced slab was approximately 10 times less than the joint ${ }_{2}$. With the use of mesh reinforcement, LTE value was approximately at least $14 \%$ higher compared to the slabs without reinforcement. 


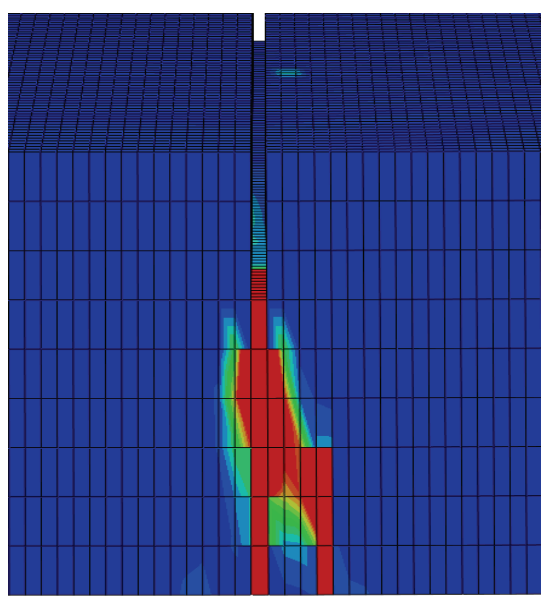

(a) FEM

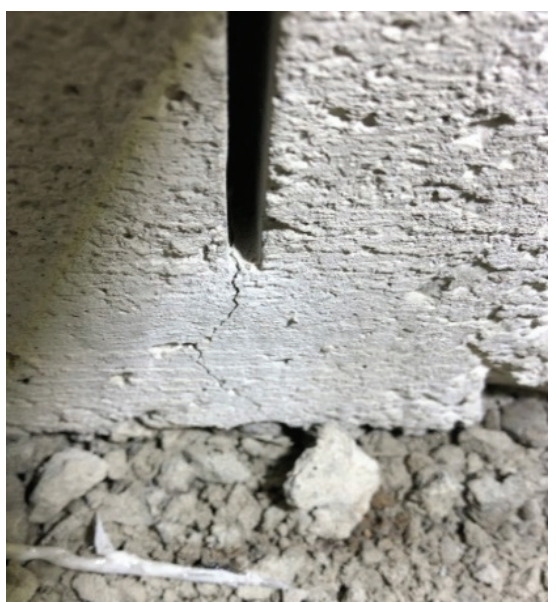

(b) APT Observation

Figure 17 - Crack formations on the side views
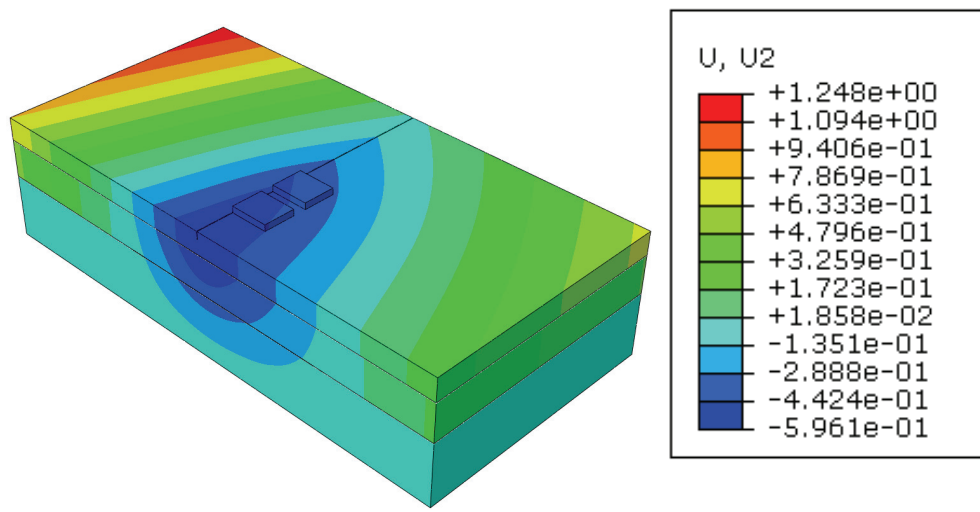

Figure 18. Vertical deformation at joint 2

Table 6 - FE analysis results at the joints

\begin{tabular}{|l|c|c|c|c|}
\hline \multirow{2}{*}{ Joint type } & \multicolumn{2}{|c|}{ Vertical deflections $(\mu \mathrm{m})$} & $\begin{array}{c}\text { LTE }(\%) \\
\left(\delta_{\mathrm{U}} / \delta_{\mathrm{L}}\right) \times 100\end{array}$ & $\begin{array}{c}\delta_{\text {ave }}(\mu \mathrm{m}) \\
\left(\delta_{\mathrm{L}}+\delta_{\mathrm{U}}\right) / 2\end{array}$ \\
\cline { 2 - 3 } & Loaded slab, $\delta_{\mathrm{L}}$ & Unloaded slab, $\delta_{\mathrm{U}}$ & 87.30 & 59 \\
\hline Reinforced joint $_{\text {(no crack) }}$ & 63 & 55 & 85.47 & 166 \\
\hline Reinforced joint $_{\text {(crack) }}$ & 179 & 153 & 72.48 & 514 \\
\hline Unreinforced joint $_{\text {(no crack) }}$ & 596 & 432 & 63.87 & 617 \\
\hline Unreinforced joint $_{\text {(crack) }}$ & 753 & 481 & & \\
\hline
\end{tabular}



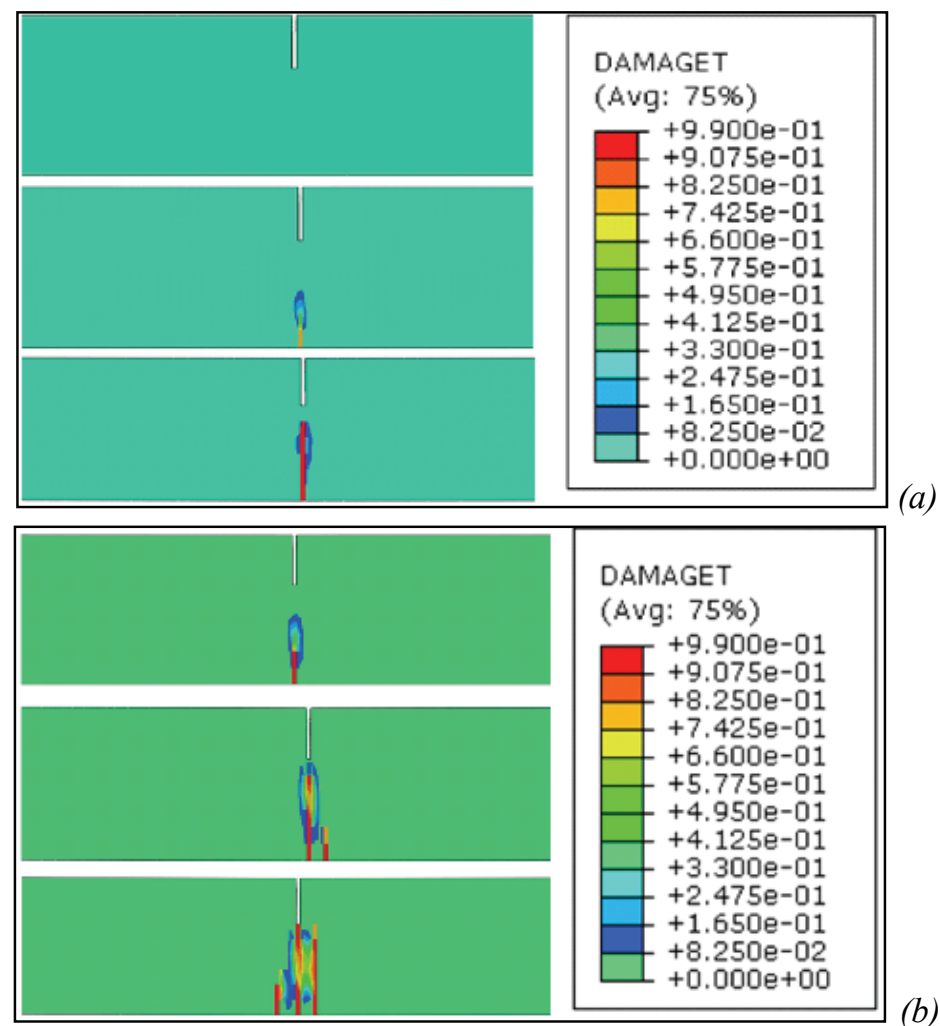

(b)

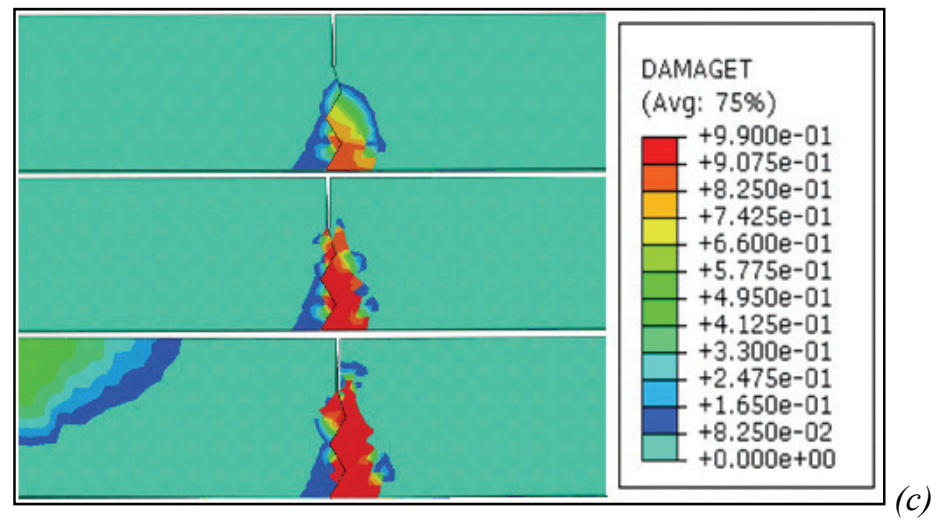

Figure 19 - Cross section view of crack propagation (a) mesh reinforced slab, (b) unreinforced slab, (c) unreinforced slab with early crack

The LTE difference between reinforced and unreinforced slabs was $16.9 \%$ before induced cracks occur, and $25.27 \%$ when cracks formed. The finite element analysis showed that contraction joint cracks tend to generate larger crack growth under the concrete slabs (Fig. 19 and Fig. 20). The cracks propagated from the bottom and merged to give continuity to the 
joint. The cracked zone indicated that the propagation of cracks resulted in ultimate failure in aggregate and cementitious materials. The finite element results showed how joint cracks can become unstable and propagate further, and develop through the full depth of the slab. The results of FE analysis and the data obtained in the APT facility were similar. The difference between the results was due to small changes in the crack model.

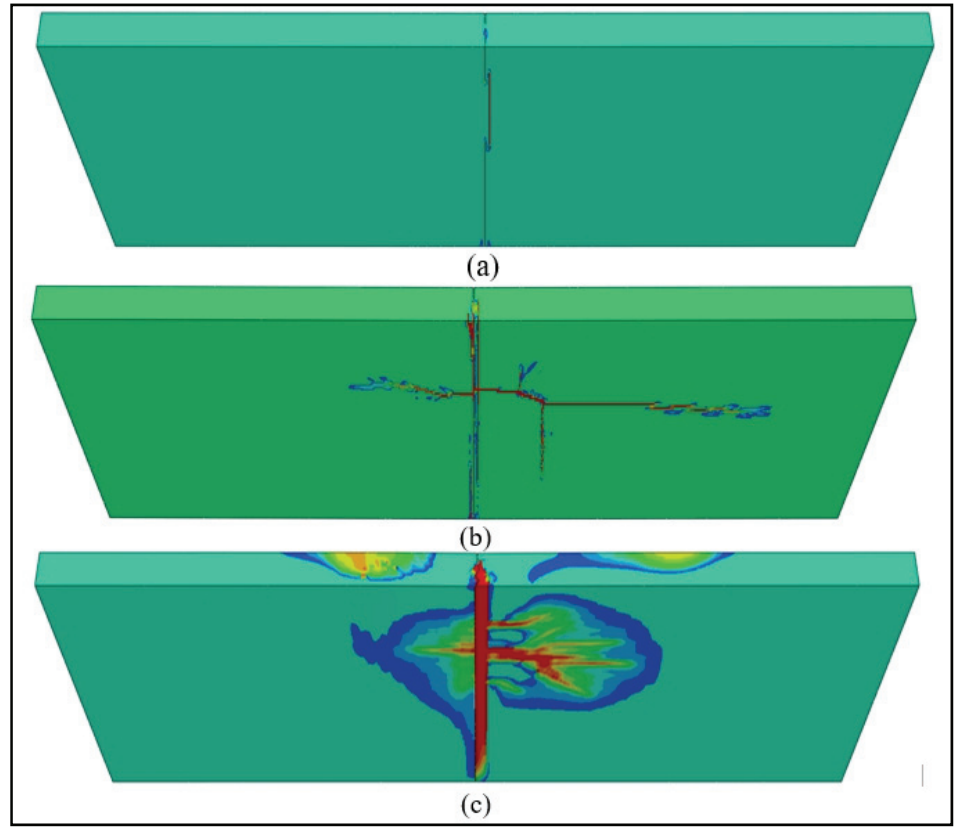

Figure 20 - Maximum crack formation under (a) mesh reinforced slab, (b) unreinforced slab, and (c) unreinforced slab with early crack.

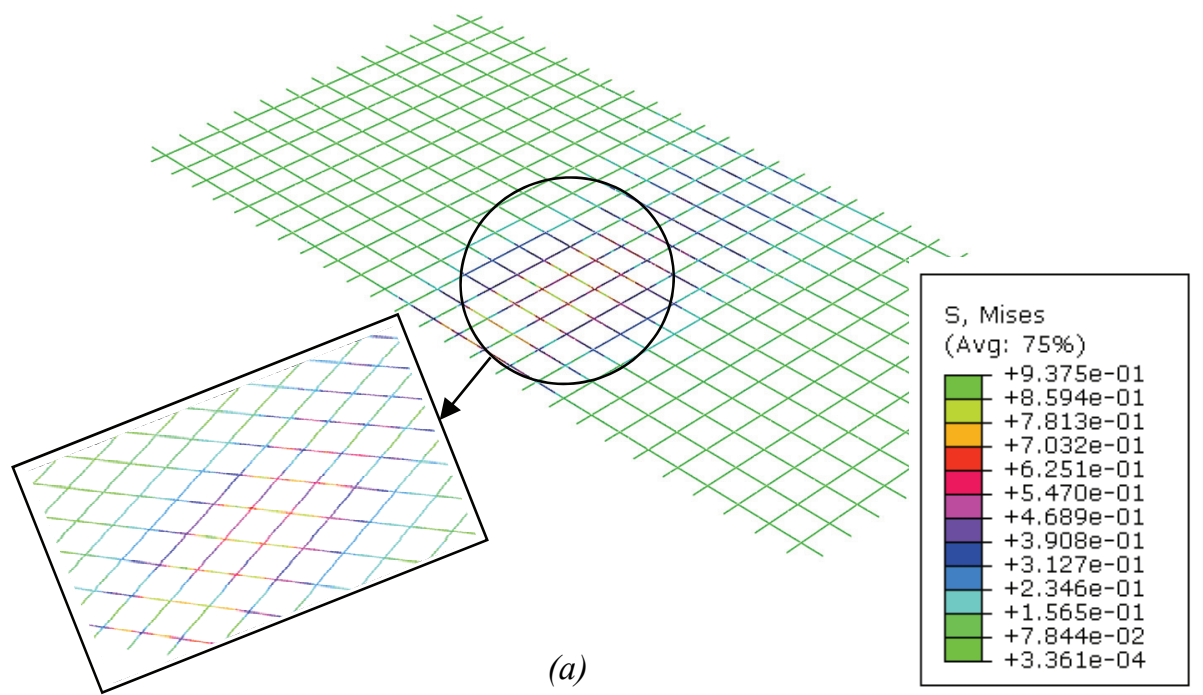



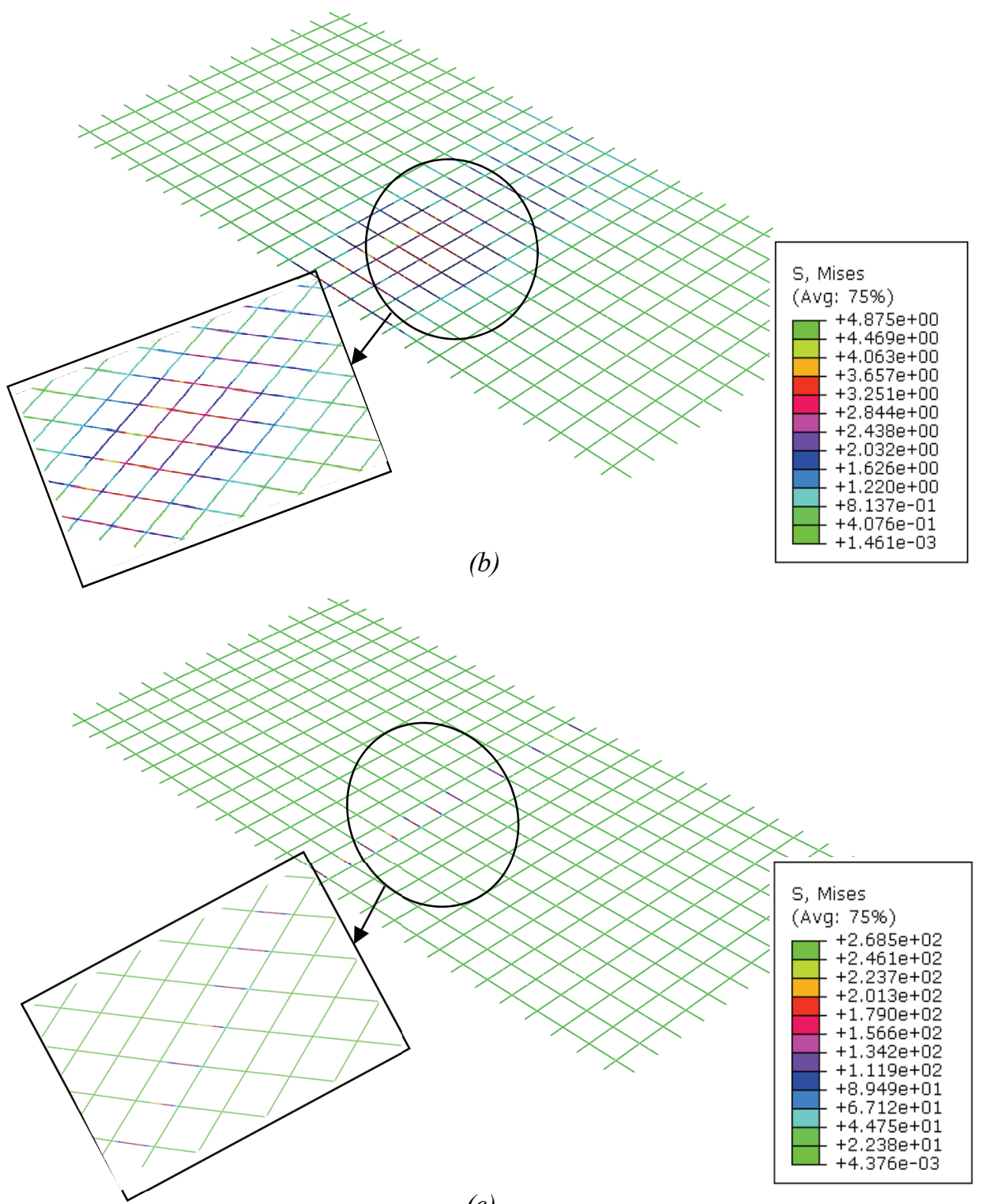

(c)

Figure 21 -Von-Mises stress distribution through the $8 \mathrm{~mm}$ steel mesh (a) at the early stage of the loading, (b) the distribution in the middle of the loading and (c) at the end of the loading protocol

Von-Mises stress distributions through the $8 \mathrm{~mm}$ steel mesh are shown in Fig. 21. When the stress distributions were examined, the maximum stress value in joint-1 (steel mesh reinforced) joint-2 and joint-3 was calculated as $13 \mathrm{MPa}, 23 \mathrm{MPa}$ and $36 \mathrm{MPa}$, respectively. 


\subsection{Cost Comparison}

Two different cross-sections were prepared for cost comparison and shown in Table 7 and 8. The calculations were made according to reinforced or unreinforced concrete slabs. The cost analysis, item numbers used in Turkish institutions such as General Directorate of Highways (KGM) and The Ministry of Environment and Urbanization (ÇŞB) were used. The road platform width was accepted as $7 \mathrm{~m}$ and the length as $1 \mathrm{~km}$ for cost calculation. The distance of the aggregate crushing plant and the road was determined as $15 \mathrm{~km}$. The base and subbase costs accepted as same in all comparisons.

Table 7 - Cost of 1- km mesh reinforced concrete pavement (2018 bid unit prices)

\begin{tabular}{|l|l|l|l|l|l|c|}
\hline \multicolumn{1}{|c|}{ Ins. } & \multicolumn{1}{|c|}{$\begin{array}{c}\text { Item } \\
\text { Number }\end{array}$} & \multicolumn{1}{|c|}{ Item Description } & Unit & $\begin{array}{c}\text { Unit Cost } \\
\text { (\$) }\end{array}$ & Amount & \multicolumn{1}{c|}{ Cost (\$) } \\
\hline MSB & MSB 322 & Concrete Pavement Construction & $\mathrm{m}^{3}$ & 35.79 & 1,260 & 45093.54 \\
\hline KGM & KGM/6000 & $\begin{array}{l}\text { Base/Subbase Construction (paving } \\
\text { irrigation compression) }\end{array}$ & $\mathrm{m}^{3}$ & 5.51 & 1,400 & 7711.48 \\
\hline ÇŞB & Y.23.010 & $\begin{array}{l}\text { A252 (8 mm wires) mesh (casualty } \\
\text { added) }\end{array}$ & Ton & 592.88 & 10.36 & 6142.22 \\
\hline ÇŞB & NYF/03 & $\begin{array}{l}\text { Transfer from Aggregate Crushing } \\
\text { Plant to the Plant (15 km) }\end{array}$ & $\mathrm{m}^{3}$ & 0.49 & 1,540 & 752.33 \\
\hline ÇŞB & NYF/07 & Transfer Steel Mesh to the Road & Ton & 8.47 & 10.36 & 87.74 \\
\hline (Without any taxes) & & \multicolumn{2}{|c|}{ TOTAL: } & & $\mathbf{5 9 , 7 8 7 . 3 0 ~ \$ ~}$ \\
\hline
\end{tabular}

Table 8 - Cost of 1- km unreinforced concrete pavement (2018 bid unit prices)

\begin{tabular}{|l|l|l|l|c|l|c|}
\hline Ins. & \multicolumn{1}{|c|}{$\begin{array}{c}\text { Item } \\
\text { Number }\end{array}$} & \multicolumn{1}{|c|}{ Item Description } & Unit & $\begin{array}{c}\text { Unit Cost } \\
\text { (\$) }\end{array}$ & Amount & Cost (\$) \\
\hline MSB & MSB 322 & Concrete Pavement Construction & $\mathrm{m}^{3}$ & 35.79 & 1,260 & 45093.54 \\
\hline KGM & KGM/6000 & $\begin{array}{l}\text { Base/Subbase Construction (paving } \\
\text { irrigation compression) }\end{array}$ & $\mathrm{m}^{3}$ & 5.51 & 1,400 & 7711.48 \\
\hline ÇŞB & NYF/03 & $\begin{array}{l}\text { Transfer from Aggregate Crushing } \\
\text { Plant to the Plant (15 km) }\end{array}$ & $\mathrm{m}^{3}$ & 0.49 & 1,540 & 0.75 \\
\hline
\end{tabular}

\section{CONCLUSIONS}

The information deduced from APT, together with FEM study, has provided useful understanding into the structural performance of reinforced and unreinforced jointed concrete pavements. The following specific conclusions are made from this study:

- LTE values of the steel mesh reinforced slab were approximately at least $14 \%$ higher compared to unreinforced slabs after 25,000 passes. 
- Considering the vertical deflections, the reinforced slab gave the lowest vertical deflections for loaded $(51 \mu \mathrm{m})$ and unloaded $(46.7 \mu \mathrm{m})$ cases. The values were almost 36 times lower than the unreinforced slabs.

- The average displacement values of both sides of the joint should be taken into consideration besides load transfer efficiency when contraction joints are evaluated at early traffic loadings.

- FE studies showed that while the stresses in the reinforcement were spread over a wide reinforcement area before the joint induced crack was formed, it was observed that after the cracking, the stress accumulations concentrated in a row of reinforcement under the joint.

- Evaluation of the LTE and vertical displacement values suggested that the use of mesh reinforcement is more favorable as it decreases both LTE and vertical displacements. Moreover, it was found that the application of the mesh reinforcement is a cost-beneficial approach, since it has been observed that $1 \mathrm{~km}$ of road costs increased by only $6,981.53$ \$(13.2\%).

\section{Acknowledgments}

This study was supported by the Scientific and Technical Research Council of Turkey (TUBITAK) (1001-Scientific and Technological Research Projects Funding Program Grant No: 217M481).

\section{References}

[1] ACI (American Concrete Institute), Joints in Concrete Construction, ACI 224.3R-95, 2001.

[2] Springenschmid, R., Reimer, B., Fleischer, W., Construction of concrete pavements in West Germany. Transportation Research Record Journal of the Transportation Research Board, 1182, 12-17, 1988.

[3] Bautista, F. E., Basheer, I., Jointed plain concrete pavement (JPCP) preservation and rehabilitation design guide, California Department of Transportation (CDOT) Division of Design, 2008.

[4] Suprenant, A. B., Saw cutting joints in concrete, 1995. Available from: https://www.concreteconstruction.net/how-to/construction/sawcutting-joints-inconcrete_o [Accessed 1 January 1995].

[5] ACI (American Concrete Institute), Guide for design and construction of new jointed plain concrete pavements (JPCPs), Report No. ACI 325.12R-02, 2002.

[6] Colley, B. E., Humphrey, H. M., Aggregate interlock at joints in concrete pavements. Bulletin HRB National Research Council, 189, 1-18, 1967.

[7] Bishoff, D., Toepel, A., Dowel bar retrofit-STH 13 Construction and one-year performance report, Report No. WI-07-02, Wisconsin Department of Transportation, 2002. 
[8] Hanekom, A. C., Horak, E., Visser, A.T., Comparison of South African and American aggregate interlock efficiency at concrete pavement joints. In: Proceedings of the 16th ASCE Engineering Mechanics Conference, University of Washington, Seattle, 2003.

[9] CDOT (California Department of Transportation), Guide for Design and Construction of New Jointed Plain Concrete Pavements (JPCPs), 2008.

[10] Darter, M., Barenberg, E., Yrjanson, W., Joint repair methods for Portland cement concrete pavements, National Cooperative Highway Research Program (NCHRP) Report No. 281, 1985.

[11] FHWA (Federal Highway Administration), Pavement subsurface drainage, Technical Guide Paper 90-01, 1990.

[12] Bennert, T. A., A rational approach to the prediction of reflective cracking in bituminous overlays for concrete pavements, Thesis (PhD), The State University of New Jersey, 2009.

[13] Khazanovich, L., Rita, L., Tompkins, D., Guidelines for the Rehabilitation of concrete pavements using asphalt overlays, Report No: FHWA TPF-5 (149), University of Minnesota, 2012.

[14] Shoukry, S. N., William, W. G., Riad, M.Y., Evaluation of load transfer efficiency measurement, Mid-Atlantic Universities Transportation Center, Report No: WVU2002-04, 2005.

[15] Sadeghi, V., Hesami S., Investigation of load transfer efficiency in jointed plain concrete pavements (JPCP) using FEM. International Journal of Pavement Research and Technology, 11 (3), 253-264, 2018.

[16] Ioannides, A. M., Korovesis, G., Aggregate interlock: a pure-shear load transfer mechanism. Transportation Research Record, 1286, 14-24, 1990.

[17] Metcalf, J. B., Application of full-scale accelerated pavement testing, NCHRP Synthesis of Highway Practice 235, TRB National Research Council, 1996.

[18] McCullough, B. F., Dossey, T., Cho, Y. H., Case study of overlay performance on rigid pavement in Bowie Country. Transportation Research Record Journal of the Transportation Research Board, 1525 (1), 107-114, 1996.

[19] Metcalf, J. B., Rasoulian, M., Romanochi, S., Yongqi, L., Construction and comparison of Louisiana's conventional and alternative base courses under accelerated loading, Lousiana Transportation Research Center (LTRC) Report No. 93-1ALF, 1998.

[20] Romanoschi, S. A., Metcalf, J. B., Li, Y., Rasoulian, M., Assessment of pavement life at the first full-scale accelerated pavement test in Louisiana, In: 1998 TRB Annual Meeting, Transportation Research Board, Washington, D.C., 1998.

[21] Li, Y., Metcalf, J. B., Romanoschi, S. A., Rasoulian, M., Soil-Cement Base Pavements under Accelerated Loading, In: 1999 TRB Annual Meeting, Transportation Research Board, Washington, D.C., 1999. 
[22] Saeed, A., Hall, J. W., Accelerated pavement testing: Data guidelines. Washington D.C.: National Cooperative Highway Research Program, NCHRP Report No. 512, 2003.

[23] Perez, S. A., Balay, J. M., Tamagny, P., Petit, Ch., Accelerated pavement testing and modelling of reflective cracking in pavements. Engineering Failure Analysis. 14 (8), 1526-1537, 2007.

[24] ACPA (American Concrete Pavement Association), Design of concrete pavement for city streets. IS184P1992, 2016.

[25] Changshun, H., Dongwei, C., Structural Study of Asphalt Concrete Overlays on the Existing Portland Cement Concrete Pavement. Journal of the Eastern Asia Society for Transportation Studies, 3 (3), 1999.

[26] Wu, R., Harvey, T., Signore, M. J., Cracking and rutting performance of composite pavements under testing with heavy vehicle simulator. Transportation Research Record Journal of the Transportation Research Board, 2304 (1), 177-184, 2012.

[27] Yin, H., Full-scale test of thermally induced reflective cracking in airport pavements. Road Materials and Pavement Design, 16 (1), 119-132, 2015.

[28] Plessis, L. D., Strauss, P. J., Perrie, B. D., Rossmann D., Accelerated pavement testing of load transfer through aggregate interlock and the influence of crack width and aggregate type - A case study, International Workshop on Best Practices for Concrete Pavements, South Africa, 2007.

[29] Joshi, S., Harle, S. M., Linear variable differential transducer (LVDT) \& its application in Civil Engineering. International Journal of Transportation Engineering and Technology, 3 (4), 62-66, 2017.

[30] Huang, Y., Evaluating pavement response and performance with different simulative tests. Thesis (PhD).Virginia Polytechnic Institute and State University, 2017.

[31] ABAQUS/CAE v6.12 Programme, Dassault Systemes Simulia Corp. Providence, RI, USA, 2017.

[32] Hüsem, M., Coşğun, S. I., Behavior of reinforced concrete plates under impact loading: different support conditions and sizes. Computers and Concrete, 18(3), 389-404, 2016.

[33] Alejano, L. R., Bobet, A., Drucker-Prager criterion. In The ISRM Suggested Methods for Rock Characterization, Testing and Monitoring: 2007-2014, 247-252, Springer, Cham, 2012.

[34] Wayessa, G. S., Quezon, E. T., Kumela, T., Analysis of stress-strain and deflection of flexible pavements using finite element method case study on Bako-Nekemte Road. Journal of Civil. Construction and Environmental Engineering, 2(4), 100-111, 2017.

[35] Khazanovich, L., Gotlif, A., Evaluation of joint and crack load transfer final report. Technical Report No. FHWA-RD-02-088, Federal Highway Administration, 2003. 
